\title{
Role of the Ventricular System in Neuroendocrine Processes: Synthesis and Distribution of Thyrotropin Releasing Factor (TRF) in the Hypothalamus and Third Ventricle
}

\author{
K. M. KNIGGE, S. A. JOSEPH D. SCHOCK, A. J. SILVERMAN \\ M. C. H. CHING, D. E. SCOTT, D. ZEMAN AND G. KROBISH-DUDLEY
}

SUMMARY In vitro biosynthesis of thyrotropin releasing factor (TRF) by different regions of the hypothalamus of mink was examined. Homogenates of hypothalamic tissue were incubated in Krebs-Ringer medium containing 200 $\mathrm{mg} \%$ glucose, $10^{5}{ }^{5} \mathrm{M}$ ATP, $0.1 \mathrm{mM}$ histidine and glutamic acid and $0.15 \mu \mathrm{c}$ ${ }^{3} \mathrm{H}$-proline (40 Ci/mmol) per $\mathrm{mg}$. tissue. Extraction, purification and estimation of ${ }^{3} \mathrm{H}$-TRF biosynthesis involved several steps of charcoal extraction, carboxymethylcellulose and sephadex chromatography. ${ }^{3} \mathrm{H}-\mathrm{TRF}$ was synthesized throughout the entire antero-posterior extent of the hypothalamus in its dorsal and medial portions. ${ }^{3} \mathrm{H}-\mathrm{TRF}$ was synthesized also in a more discreet

RÉSUMÉ Biosynthèse in vitro à de différentes régions hypothalamiques chezle vison, du "thyrotropin releasing factor" (TRF) fut étudiée. Homogenats de tissu hypothalamique furent incubés en préparation Krebs-Ringer contenant $200 \mathrm{mg} \%$ glucose, $10-5 \mathrm{M}$ ATP, $0.1 \mathrm{mM}$ histidine et acide glutamique ainsi que $0.15 \mathrm{M} \mathrm{c}^{3}$ $H$-proline $(4 \hat{O} \mathrm{Ci} / \mathrm{mmol})$ pour $\mathrm{mg}$. de tissu. Extraction, purification et estimation de biosynthèse de ${ }^{3} \mathrm{H}$-TRF nécessitèrent plusieurs procédures d'extraction avec charbon, ainsi que chromatographie avec carboxymethyl-cellulose et sephadex. ${ }^{3} H-T R F$ fut synthétisé à l'étente entière antéro-postérieure hypothalamique, à ses régions dorsales et médiales. Le même fut synthétisé aussi à une région plus restreinte, au noyau region, the arcuate nucleus. In vitro biosynthesis of ${ }^{3} \mathrm{H}-\mathrm{TRF}$ was stimulated significantly by thyroxine, but not by TSH, estradiol, corticosterone or melatonin. A method is described for collection of cerebrospinal fluid of the third ventricle of the rat brain; TRF concentration in this fluid was approximately 18 $\mathrm{pg} / \mathrm{Ml}$ in normal animals.

The distribution of TRF-producing cells in the hypothalamus and presence of TRF in cerebrospinal fluid of the third ventricle is discussed with respect to the hypothesis that this releasing factor may be delivered to the median eminence and adenohypophysis in part, via the cerebrospinal fluid.

arcué. Biosynthèse in vitro de ${ }^{3} \mathrm{H}$-TRF fut stimule par thyroxine, mais non par TSH, estradiol, corticostérone ni melatonin. Une méthode est décrite pour collection de liquide céphalorachidien du troisième ventricule cérébral chez le rat; la concentration de TRF en ce liquide fut environ $18 \mathrm{pg} / \mathrm{U} I$ chez l'animal normal.

La distribution topographique de cellules fabriquant TRF à l'hypothalamus ainsi que la présence de TRF au liquide céphalorachidien du troisième ventricule, sont discutés par rapport à l'hypothèse que cette substance soit apportée à l'éminence médiane et à l'adénohypophyse en partie par le liquide céphalorachidien.

From the Department of Anatomy University of Rochester School of Medicine and Dentistry Rochester. New York 14642

Reprint Address: Dr. K. M. Knigge, Dept. of Anatomy, University of Rochester, School of Medicine and Dentistry, Rochester, New York 14642.

\section{INTRODUCTION}

The several contributors to this symposium have provided excellent reviews of our current knowledge of some structural and functional aspects of the endocrine hypothalamus; they have also shared with us glimpses of some exciting new directions which lie on the horizon. I would like to address myself also to some basic but unresolved questions regarding neural control of the pituitary gland.

The endocrine hypothalamus Knigge and Silverman, (1973) is a subsystem of the diencephalic hypothalamus concerned with regulation of pituitary gland function and integration of endocrine motor control with appropriate viscero-and somatomotor activity to achieve optimal homeostasis and adaptive capability of the organism. This integration of brain and peripheral endocrine function is accomplished by (a) a specialized pool of putative neurones, the "parvicellular" RFproducing neurones, whose secretions (releasing factors: hypophysiotropins) influence adrenohypophyseal function, (b) intrinsic hypothalamic subcircuits which provide for coordinated response with other efferent systems represented in the hypothalamus (temperature regulation, food intake, etc.), and (c) closed loop feedback influences from hormones of the peripheral endocrine organs, including the adenohypophysis. 
There are four essential areas of research relating to normal structure and function of the endocrine hypothalamus which I believe are fundamental to our continuing understanding of this division of the nervous system. These are (1) the chemical identity of the several releasing factors, (2) the identity and localization of the cells responsible for their elaboration, (3) the manner in which these hormones are delivered to the adenohypophysis, and (4) the factors (neural and hormonal) which influence their secretion, delivery and terminal action. We have been examining since 1968, Knigge, et al., (1971) the possibility that the cerebrospinal fluid may be part of the route over which brain hormones are delivered to the adenohypophysis. The following sections present data relevant to this question.

\section{SYNTHESIS OF TRF REGIONALLY IN HYPOTHALAMUS OF THE MINK}

The availability of natural, synthetic and radiolabeled TRF and development of methods to demonstrate in vitro hypothalamic biosynthesis of this hormone afford opportunities to explore many basic aspects of the physiology of the endocrine hypothalamus. An important issue is the regional localization within the hypothalamus of the cells responsible for production of TRF.

In these studies we have used the brains from mink (Mustela vison). After removal of the brain and prior to subdivision of the hypothalamus, the median eminences were separated by dissection, Silverman et al (1972). When dissected this way, the median eminence contains none of the adjacent tissue of the arcuate nucleus. These were used for biosynthesis studies and for other experiments on transport capacity of this tissue, Silverman et al (1972b), Silverman and Knigge (1972). The brain was then hardened by rapidly cooling it for $1-2$ hours at $-70^{\circ} \mathrm{C}$, allowing subdivision of the hypothalamus into different regions; some brains were kept at this temperature for up to $2^{1 / 2}$ years before use.

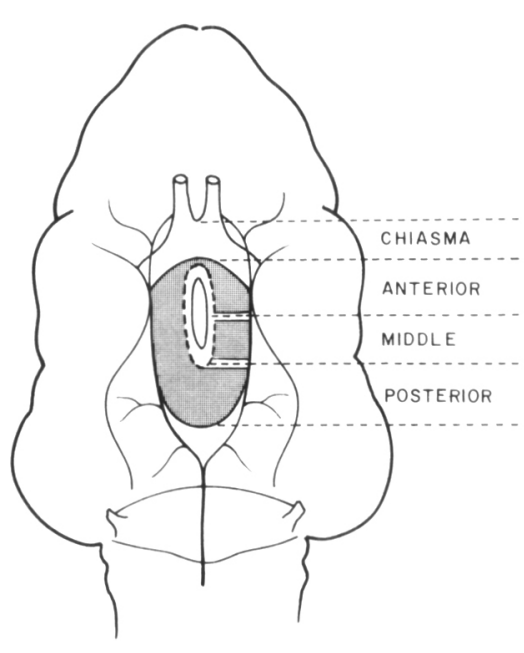

Figure 1 -Diagram of the ventral aspect of the mink brain. After resection of the median eminence the 3 rd ventricle and its recess are clearly delineated. Horizontal lines indicate the planes of section along which the hypothalamus was divided into four regions. The carotid distribution along the hypothalamic sulcus served to define the lateral boundary of hypothalamus.

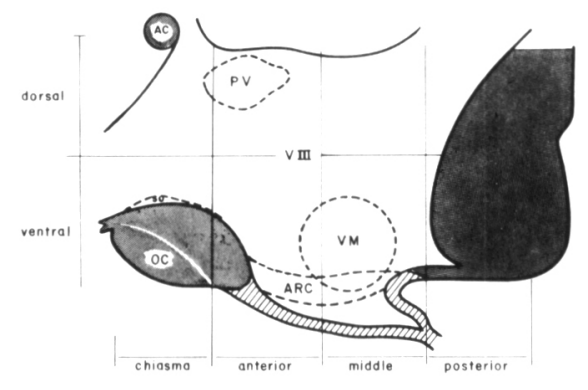

Figure 2-Midsaggital projection of the mink hypothalamus, reconstructed from serial histological sections. Superimposed on the projection are lines indicating the dorso-ventral partitioning of the chiasma, anterior, middle and posterior regions used for biosynthesis studies. AC-anterior commissure; OC-optic chiasma; PVparaventricular nucleus; SO-supraoptic nucleus; VM-ventromedial nucleus; ARC-arcuate nucleus. Hatching indicates the extent of median eminence.

All dissection was performed under a dissecting microscope at magnification of $30 \mathrm{X}$. Figure 1 illustrates diagramatically a ventral view of the brain and landmarks used to section the hypothalamus into four antero-posterior regions from optic chiasm to mammillary body. After these initial cuts were made, the slices were laid over to view them as frontal sections. Lateral boundries of the hypothalamus were identified by the internal carotid artery; dorsally the tissue was cut approximately $1 \mathrm{~mm}$ above the anterior commissure in the chiasma section and $1 \mathrm{~mm}$ above the 3 rd ventricle in the remaining three sections. Dorsalventral divisions were made to divide the sections into equal upper and lower pieces; medial-lateral divisions were made to divide each half of the hypothalamus into equal portions. Figure 2 illustrates the divisions of hypothalamus in a midsaggital projection.

A total of $200-600 \mathrm{mg}$ of tissue (generally from 10 hypothalami) was used for each incubation. A variety of tissue preparations ranging from minced whole tissue up to $100,000 \mathrm{xg}$, particle-free supernatant were examined. For the purposes of this study, a simple supernatant after moderate centifugation was found most convenient, easy to process and consistent in its ability to synthesize TRF. After weighing, the tissue was homogenized in a glass homogenizer containing $5 \mathrm{ml}$ of oxygenated Krebs-Ringer Bicarbonate buffer with $400 \mathrm{mg} \%$ glucose $\mathrm{pH} 7.4$ to which the following supplements were added: $0.1 \mathrm{mM}$ histidine, $0.1 \mathrm{mM}$ glutamic acid and $10-5 \mathrm{M}$ ATP. The homogenate was centrifuged at 14,000 rpm (Serval M2, SS-34 head, creating $23,000 \mathrm{xg}$ ) for 1 hour; the supernatant was transferred to a $20 \mathrm{ml}$ beaker and ${ }^{3} \mathrm{H}$-proline $(38 \mathrm{Ci} / \mathrm{mmol})$ added at a concentration of $0.15 \mathrm{uc} / \mathrm{mg}$ original wet weight of tissue. Incubation was carried out in a Dubnoff metabolic shaker for 4-6 hours in an atmosphere of $95 \% \mathrm{O}_{2}$ - $5 \% \mathrm{CO}_{2}$, after which the solution was transferred to a test tube, stoppered and frozen until processed further.

The recovery and estimation of amount of ${ }^{3} \mathrm{H}$-TRF synthesized by these homogenates of mink hypothalami were accomplished by five sequential extraction and purification steps which were: (1) charcoal absorption from incubation media, (2) carboxymethyl cellulose (CMC) chromatography, (3) charcoal extrac- 
tion of CMC eluates (4) Sephadex chromatography, and (5) charcoal extraction of Sephadex eluates. Several incubates have been carried one additional step, namely, assay of biological activity for the purpose of establishing specific activity of the synthesized hormone.

Charcoal used for adsorption of TRF was prepared in the following manner. Two hundred $\mathrm{ml} 0.01 \mathrm{~N}$ acetic acid was added to $8 \mathrm{~g}$ charcoal (norit-A) and stirred for two hours at room temperature. The mixture was centrifuged at $2500 \mathrm{rpm}$ for 10 minutes and the charcoal precipitate suspended in $10 \mathrm{ml}$ distilled water. After centrifuging again, the precipitate was resuspended in $200 \mathrm{ml}$ of $95 \%$ ethanol and stirred two hours at room temperature. This mixture was centrifuged and the charcoal precipitate resuspended in $80 \mathrm{ml}$ of distilled water. From this stock solution $1: 4$ dilution with $0.1 \mathrm{~m}$ sodium phosphate buffer, pH 7.4 was made for TRF adsorption as described below.

At step $1,0.5 \mathrm{ml}$ of charcoal suspension was added to $5 \mathrm{ml}$ of incubation medium, agitated, refrigerated for one hour and centrifuged. After washing with three $2.0 \mathrm{ml}$ volumes of sodium phosphate buffer, TRF was eluted from the charcoal with six $2.0 \mathrm{ml}$ volumes of $90 \%$ ethanol. Each extraction was refrigerated 20-30 minutes before centrifugation. The eluate was filtered through a $45 \mathrm{u}$ pore size Millipore filter and evaporated to dryness in preparation for CMC chromatography.

At step $3,18 \mathrm{ml}$ aliquots of eluate from the $\mathrm{CMC}$ column were brought to $\mathrm{pH} 7.0$ with dilute $\mathrm{NH}_{4} \mathrm{OH}$ and $1.0 \mathrm{ml}$ charcoal suspension added, agitated and refrigerated for one hour. After centrifugation, the charcoal precipitate was washed 3 times with $5 \mathrm{ml}$ volumes of phosphate buffer. TRF was eluated from the charcoal with three $2.5 \mathrm{ml}$ volumes of $90 \%$ ethanol and the combined eluate evaporated to dryness in preparation for Sephadex chromatography. Recovery of TRF in these steps was always better than $95 \%$. At step 5, $15 \mathrm{ml}$ aliquots of $1 \mathrm{~N}$ acetic acid from the Sephadex column were neutralized with $10 \mathrm{~N} \mathrm{NaOH}$ to $\mathrm{pH}$ $7.4 ; 300 \mathrm{mg}$ alumina was added, agitated and allowed to stand 15 minutes at room temperature. After centrifugation, TRF was extracted from the supernatant with charcoal as in step 3.

Carboxymethylcellulose (Brinkman MN2100CM) columns (25 $\mathrm{x}$ $500 \mathrm{~mm}$ ) were equilibrated with .002 $\mathrm{M}$ ammonium acetate, $\mathrm{pH} 4.5$; after application of the residue of step 1, the column was run at approximately $2 \mathrm{ml} / \mathrm{min}$. and a gradient elution achieved by introducing $0.1 \mathrm{M}$ ammonium acetate at $\mathrm{pH} 7.0$ into 100 $\mathrm{ml}$ of $.002 \mathrm{M}$ buffer contained in the lower reservoir. Ten $\mathrm{ml}$ aliquots of the eluate were collected. Standard ${ }^{3} \mathrm{H}$-TRF is restricted almost exclusively to tubes $40-42 ;{ }^{3} \mathrm{H}$-proline appears in tubes 18-20, with approximately $0.5-1 \%$ of ${ }^{3} \mathrm{H}$-proline activity applied to the column being carried into the TRF zone.

In step 4, samples were applied to a $25 \times 500 \mathrm{~mm}$ column of Sephadex G-25, equilibrated and run in $1 \mathrm{~N}$ acetic acid. Five $\mathrm{ml}$ aliquots of the eluate were collected; standard ${ }^{3} \mathrm{H}$ TRF appears in tubes 36-38.

Table 1 summarizes the several purification steps and illustrates the yield of radioactivity of ${ }^{3} \mathrm{H}$-TRF recovered. Satisfactory estimates of TRF biosynthesis are possible after Sephadex chromatography (step 4);
In the majority of experiments, therefore, the area under the major peak after Sephadex chromatography was considered a measure of radio-activity incorporated into hormone. The overall recovery of standard ${ }^{3} \mathrm{H}-\mathrm{TRF}$ through these several steps was approximately $20 \%$

For assay and estimation of the specific activity of synthesized ${ }^{3} \mathrm{H}-\mathrm{TRF}$, the in vitro assay method of Joseph et al (1973) was used. Since this assay, based upon in vitro release of pituitary $\mathrm{TSH}$, does not differentiate between any endogenous TRF present initially and synthesized (radiolabeled) TRF, assays were performed to identify these two pools of hormone. Homogenates of $500 \mathrm{mg}$ of the anterior-middle region of the hypothalamus, without incubation, were processed through all the purification and recovery steps outlined above. The residue from charcoal extraction step 5 of only four incubations (Expt. 3, Table 2) have been assayed thus far. Preliminary results suggest a molar incorporation of the precursor into hormone under conditions of these incubations.

\section{BIOSYNTHESIS OF TRF BY MINK HYPOTHALAMUS}

Tables 2 and 3 summarize the results of several experiments on TRF biosynthesis by various regions

\section{TABLE 1}

Yield of radioactivity and TRF following 5 hour incubations of homogenates from $500 \mathrm{mg}$ hypothalamus or cortex with $1.96 \times 10^{8} \mathrm{dpm}$ ${ }^{3} \mathrm{H}$-proline (38 Cilmmol).

Purification step

1. charcoal adsorption

2. CMC chromatography

3. charcoal adsorption

4. Sephadex chromatography

5. charcoal adsorption

TRF is eluted as one major peak with 1 or 2 impurities occasionally evident as smaller, following peaks. Upon charcoal adsorption of the TRF in the major Sephadex peak, 92$95 \%$ of the radioactivity is recovered.

Hypothalamus
$1.92 \times 10^{6}$
79,200
11,900
9,200
8,800

Yield, dpm Cortex

of mink hypothalamus. Several general observations deserve comment. Hypothalamic tissue can be frozen for considerable periods of time without significant loss of enzyme activity; in Experiment 3 
(Table 2), tissue stored at $-70^{\circ} \mathrm{C}$ for $2 \frac{1}{2}$ years was still capable of TRF synthesis although the yield was diminished. The hypothalami of female mink (Expts. 3 and 4, Table 2) synthesized approximately three times as much TRF as male hypothalami (Expts. 1, 2, 5 and 6, Table 2). This apparent sex difference is being currently explored in more detail.

Experiments 2 and 3 (Table 2) indicate that TRF may be synthesized in all four of the antero-posterior regions of hypothalamus as dissected in this study. Approximately $60 \%$ of the total amount of hormone recovered (Expt. 2), however, was made in the anterior and middle zones of the hypothalamus.
In Experiments 5-7, the medio-lateral and dorso-ventral distribution of TRF-producing elements in the hypothalamus was examined. For these subdivisions, the combined anterior and middle region of the hypothalamus was used. In Experiment 5, this block of hypothalamus was first separated into right and left halves, then each half cut into approximately equal medial and lateral portions; in Experiment 6, the anterior-middle biock of hypothalamus was subdivided into equal dorsal and ventral pieces. Incubations of tissue homogenates from these hypothalamic regions indicate that the medial half of hypothalamus is capable of at least four times greater biosynthesis of TRF than lateral

\section{TABLE 2}

In vitro biosynthesis of TRF regionally in hypothalamus of mink. Yield of ${ }^{3} \mathrm{H}-\mathrm{TRF}$ is expressed as radioactivity (dpm) of incorporated ${ }^{3} \mathrm{H}$-proline precursor.

\begin{tabular}{|c|c|c|c|c|c|c|c|}
\hline \multirow[b]{2}{*}{ Experiment } & \multirow{2}{*}{$\begin{array}{c}\text { Hypothalamic } \\
\text { Region }\end{array}$} & \multirow{2}{*}{$\begin{array}{l}\text { No. } \\
\text { Pieces }\end{array}$} & \multirow{2}{*}{$\begin{array}{l}\text { wt., } \\
\text { mg }\end{array}$} & \multirow[b]{2}{*}{ Conditions } & \multicolumn{3}{|c|}{${ }^{3} \mathrm{H}-\mathrm{TRF}$ synthesis } \\
\hline & & & & & dpm. total dpr & $\mathrm{pm} / \mathrm{hypothalamic}$ & piece \\
\hline \multirow[t]{3}{*}{1} & whole (rat) & 12 & 510 & fresh tissue & 2,360 & 197 & \\
\hline & whole (rat) & 12 & 405 & “" & 2,380 & 198 & \\
\hline & cortex (rat) & & 420 & “" & 500 & $\cdots$ & \\
\hline \multirow[t]{5}{*}{2} & whole (mink) & 10 & 1,503 & frozen $6 \mathrm{mo}$ & 26,656 & 2,666 & \\
\hline & chiasma & 10 & 327 & “ & 9,044 & 904 & \\
\hline & anterior & 10 & 447 & “" & 12,376 & 1,238 & \\
\hline & middle & 10 & 455 & ““ & 11,424 & 1,142 & \\
\hline & posterior & 10 & 491 & “" & 8,092 & 809 & \\
\hline \multirow[t]{3}{*}{3} & anterior (A) & 10 & 414 & frozen $2 \frac{1}{2}$ yrs. & 3,527 & 357 & \\
\hline & middle $(\mathrm{M})$ & 10 & 462 & “" & 2,380 & 238 & \\
\hline & posterior & 10 & 426 & “ & undetectable & $\cdots$ & \\
\hline \multirow[t]{4}{*}{4} & ant.-mid. (AM) & 10 & 614 & fresh tissue & 8,092 & 809 & \\
\hline & “ & 10 & 603 & “" & 9,948 & 995 & \\
\hline & “" & 10 & 733 & frozen $1 \mathrm{yr}$. & 13,804 & 1,380 & \\
\hline & “ & 10 & 860 & “ & 9,044 & 904 & \\
\hline \multirow[t]{4}{*}{5} & AM (medial) & 10 & 310 & fresh tissue & 19,992 & 2,000 & \\
\hline & AM (medial) & 10 & 238 & “ & 25,760 & 2,576 & \\
\hline & AM (lateral) & 10 & 425 & “ & 7,092 & 709 & \\
\hline & AM(lateral) & 10 & 327 & “ & 4,181 & 418 & \\
\hline \multirow[t]{2}{*}{6} & AM (dorsal) & 10 & 435 & fresh tissue & 8,092 & 809 & \\
\hline & AM (ventral) & 10 & 245 & & 3,808 & 381 & \\
\hline \multirow[t]{4}{*}{7} & AM (dorsal) & 10 & 410 & fresh tissue & 10,472 & 1,047 & \\
\hline & AM (ventral) & 10 & 440 & “ & 4,284 & 428 & \\
\hline & arcuate $\mathrm{N}$ & 20 & 180 & “ & 11,424 & 571 & \\
\hline & $\begin{array}{l}\text { median } \\
\text { eminence }\end{array}$ & 200 & 285 & "“ & undetectable & $\cdots$ & \\
\hline
\end{tabular}

hypothalamus and the dorsal portion more than the ventral by a factor of 2 or 3. (Table 2). In Experiment 7 the ventral half of the hypothalamus was studied in further detail by examining biosynthesis of TRF in the median eminence and in the arcuate nucleus. After removal of the median eminence, two long pieces of the exposed lips of the medial hypothalamic wall corresponding to the antero-posterior extent of the arcuate nucleus were excised with straight microscissors. The amount of tissue dissected from each hypothalamus weighed $8-9 \mathrm{mg}$ and represented approximately one-fifth of the tissue in experiments 6 and 7 designated as the ventral half of the anterior-middle hypothalamus region.

Median eminence (200 pieces, 285 $\mathrm{mg}$ ) synthesized no detectable amount of TRF, while incubation of $140 \mathrm{mg}$ of tissue of the arcuate region from 20 hypothalami (Table 2) resulted in synthesis of TRF (571 $\mathrm{dpm} /$ piece) equal to that produced by the entire ventral half of the anteriormiddle region $(428 \mathrm{dpm} /$ piece) .

Table 3 summarizes several experiments which examined factors influencing biosynthesis of TRF. In several of these experiments, incubations were carried out in Media 199 containing additional glucose $(100 \mathrm{mg} \%)$ and $10^{-5} \mathrm{M}$ ATP; in vitro TRF biosynthesis was not notably increased under these conditons. In Experiment 2 (Table 3) the presence of $10^{-7} \mathrm{M}$ estradiol did not appear to notably influence hormone production; $10^{-7} \mathrm{M}$ corticosterone may have a slight stimulatory effect. In Experiments 3 and 4 (Table 3 ) thyroxine in concentrations ranging from $5 \mathrm{X}$ $10^{-7} \mathrm{M}$ to $10^{-4} \mathrm{M}$ produced a doserelated, stimulatory effect upon TRF biosynthesis; at $10^{-4} \mathrm{M}$, a 35 -fold increase in hormone production was obtained. Neither TSH (Experiment 5) nor melatonin (Experiment 6) influenced TRF biosynthesis.

An initial projection of TRF biosynthesis rate is possible with the data obtained in these experiments. Considering the several factors involved in such a calculation (incubation time, recovery, molar 
TABLE 3

Effect of several peripheral target organ hormones upon in vitro biosynthesis of ${ }^{3} \mathrm{H}-\mathrm{TRF}$.

\begin{tabular}{|c|c|c|c|c|c|}
\hline \multirow{3}{*}{$\begin{array}{c}\text { Experi- } \\
\qquad 1\end{array}$} & \multirow{3}{*}{$\begin{array}{c}\text { No. } \\
\text { Pieces } \\
\text { (sex) } \\
10(\mathrm{M})\end{array}$} & \multirow{2}{*}{$\begin{array}{l}\text { Wt.. } \\
\text { mg }\end{array}$} & \multirow{2}{*}{$\begin{array}{l}\text { Conditions } \\
\text { dpm,total }\end{array}$} & \multicolumn{2}{|c|}{${ }^{3} \mathrm{H}-\mathrm{TRF}$ synthesis } \\
\hline & & & & \multicolumn{2}{|c|}{$\mathrm{dpm} / \mathrm{hypothalamic} \mathrm{piece}$} \\
\hline & & & Krebs-Ringer media & 5,712 & 571 \\
\hline & 10 & 643 & Media 199 & 6,666 & 667 \\
\hline \multirow[t]{5}{*}{2} & $10(\mathrm{M})$ & 552 & $\mathrm{~K}-\mathrm{R}$ media & 8,754 & 875 \\
\hline & 10 & 531 & $10{ }^{7} \mathrm{M}$ estradiol & 14,280 & 1,428 \\
\hline & 10 & 491 & & 11,424 & 1,142 \\
\hline & 10 & 505 & $10-{ }^{7} \mathrm{M}$ corticosterone & 15,708 & 1,571 \\
\hline & 10 & 522 & & 33,760 & 3,376 \\
\hline \multirow[t]{4}{*}{3} & $10(F)$ & 492 & $\mathrm{~K}-\mathrm{R}$ media & 26,200 & 2,620 \\
\hline & 10 & 499 & $5 \times 10^{-7} \mathrm{M}$ thyroxine & 21,896 & 2,190 \\
\hline & 10 & 460 & $5 \times 10^{6} \mathrm{M}$ thyroxine & 36,600 & 3,660 \\
\hline & 10 & 487 & $5 \times 10-5 \mathrm{M}$ thyroxine & 121,600 & 12,160 \\
\hline \multirow[t]{4}{*}{4} & $10(F)$ & 451 & Media 199 & 21,800 & 2,180 \\
\hline & 10 & 431 & $1 \times 10-{ }^{6} \mathrm{M}$ thyroxine & 145,000 & 14,500 \\
\hline & 10 & 490 & $1 \times 10-5 \mathrm{M}$ thyroxine & 250,000 & 25,000 \\
\hline & 10 & 462 & $1 \times 10-4 \mathrm{M}$ thyroxine & 771,000 & 77,100 \\
\hline \multirow[t]{3}{*}{5} & $10(\mathrm{M})$ & 677 & Media 199 & 7,140 & 714 \\
\hline & 10 & 711 & $1 \mathrm{mu} \mathrm{TSH} / \mathrm{ml}$ & 6,664 & 666 \\
\hline & 10 & 640 & $5 \mathrm{mu} \mathrm{TSH} / \mathrm{ml}$ & 7,616 & 762 \\
\hline \multirow[t]{2}{*}{6} & $10(\mathrm{M})$ & 697 & Media 199 & 9,044 & 904 \\
\hline & 10 & 697 & $100 \mathrm{ug} / \mathrm{ml}$ melatonin & 8,568 & 857 \\
\hline
\end{tabular}

incorporation of ${ }^{3} \mathrm{H}$-proline, presence of approximate physiological ranges of thyroxine concentration), an in vitro synthesis rate of $1-3$ $\mathrm{pg} / \mathrm{min}$, may be derived.

\section{CONTENT OF TRF REGIONALLY \\ IN HYPOTHALAMUS IN MINK}

The localization of endogenous hormone in the hypothalamus of the mink was examined by extraction and bioassay. In these studies (by M.C.H.C.), the hypothalamus was subdivided into only three primary antero-posterior divisions (anterior, middle and posterior) instead of four as in the previous experiments; the sectioning was such that "middle" and "posterior" regions in the two sets of experiments are comparable and the anterior region of this study equivalent to the anterior plus chiasma regions of the biosynthesis studies.

Following excision of the median eminence, brains from 105 freshly killed adult male mink were hardened at $70^{\circ} \mathrm{C}$; the hypothalamus was subdivided into an anterior, middle, and posterior third. Each of these regions was subdivided further, under a dissecting microscope, into a dorsal and ventral half, and each half then subdivided into a middle and two lateral segments. Fragments from each of these 12 hypothalamic regions were rinsed in saline, blotted on filter paper and pooled in $10 \mathrm{ml}$ absolute methanol. Cerebral cortex tissue, approximately equivalent in mass to the collections of hypothalamic tissue, served as control material. The pooled tissue fragments, representing each of the 12 hypothalamic regions and cerebral cortex were homogenized in $10 \mathrm{ml}$ absolute methanol. After centrifuging for 10 minutes at $1000 \mathrm{xg}$, the supernatant was decanted and the precipitate extracted with an additional $5 \mathrm{ml}$ absolute methanol. The two supernatants were combined and stored overnight at $-20^{\circ} \mathrm{C}$. A white flocculant precipitate which appeared upon cooling was removed by repeated centrifugation and freezing of the alcoholic supernatant. The clear extract was then evaporated under nitrogen gas at $37^{\circ} \mathrm{C}$, yielding a lightyellowish residue. This residue was reconstituted in $5 \mathrm{ml}$ of $0.1 \mathrm{M}$ phosphate buffer, $\mathrm{pH} 7.5$, and TRF extracted with charcoal as previously described. After drying the pooled alcoholic eluate, the residue was reconstituted at the time of assay in $1.05 \mathrm{ml} \mathrm{3 \%}$ ethanol. TRF was quantified in each of the 12 hypothalamic regions and cerebral cortex by a modification of the McKenzie bioassay for TSH as described by Redding, et al. (1966). Standards of synthetic TRF (3.125-25ng) yielded a suitable log-dose response curve with the lower limit of detectability of approximately $3 \mathrm{ng}$. Because of the relative insensitivity of this assay and from preliminary information on total hypothalamic content of TRF in the mink, the extracts of hypothalamic regions were assayed at a single dose only; four mice each received 0.25 $\mathrm{ml}$ of the extract, equivalent to 25 regional segments of the hypothalamus.

\section{TABLE 4}

Regional localization of endogenous TRF in the hypothalamus of mink. A pool of 100 pieces of each of the twelve hypothalamic regions was assayed for its hormone content; results are expressed as ng TRF/I hypothalamic region.

\begin{tabular}{|c|c|c|c|}
\hline \multicolumn{2}{|c|}{ Hypothalamic Region } & Medial & Lateral \\
\hline \multirow[t]{2}{*}{ Anterior } & dorsal & 0.98 & 0.52 \\
\hline & ventral & 0.33 & 0.16 \\
\hline \multirow[t]{2}{*}{ Middle } & dorsal & 0.30 & 0.13 \\
\hline & ventral & 0.68 & 0.12 \\
\hline \multirow[t]{2}{*}{ Posterior } & dorsal & 0.13 & 0.14 \\
\hline & ventral & 0.13 & 0.14 \\
\hline
\end{tabular}

Table 4 indicates the distribution of endogenous TRF found regionally in the hypothalamus of mink. Although some TRF was detected in all regions of the hypothalamus, it was noticeably concentrated medially in a dorsal, anterior region and in a ventral, middle zone. Cerebral cortex contained no TRF. 


\section{PRESENCE OF TRF IN CEREBROSPINAL FLUID OF \\ THE THIRD VENTRICLE}

The possibility that releasing factors may be delivered to the adenohypophysis by a route involving the cerebrospinal fluid requires that the hormones be present in the CSF. We have examined this possibility by collecting CSF from the third ventricle and measuring its TRF concentration.

Cerebrospinal fluid from the third ventricle was collected in the following manner. Adult male rats were sacrificed by decapitation; as much bone of the skull as possible was excised carefully with rongeurs and the brain removed with minimal mechanical pressure or distortion. Under a dissecting microscope ( $\mathrm{x} 40)$, the free end of the pituitary stalk was grasped with fine pointed forceps and lifted to allow visualization of the posterior aspect of the stalk and the median eminence. With appropriately directed incident illumination, the mammillary recest of the third ventricle was clearly visible. A glass microcannula was inserted into the ventricle at this point and moved anteriorly into the ventricular recess; the tip of the cannula was seen easily through the median eminence. Cerebrospinal fluid ascended in the microcannula by capillary action; it was expelled from the cannula by positive pressure into a beaker containing $0.5 \mathrm{ml}$ Krebs-Ringer Bicarbonate (KRB) buffer. The optimal size of the microcannula was found to be approximately $0.15 \mathrm{~mm}$ outer diameter by $60-75 \mathrm{~mm}$ length. Calibration was accomplished by weighing the empty cannula, filling it with distilled water by capillary action, measuring the length of the column of water in the cannula and reweighing it; from this a measure of the volume per $\mathrm{mm}$ of cannula is derived. After collection of CSF, the length of the column of the CSF was recorded and volume calculated. The amount of CSF collected by this technique ranged from $0.3-0.5$ ul per animal. CSF of the third ventricle from 10-15 animals per group was pooled in the initial $0.5 \mathrm{ml} \mathrm{KRB}$ and this subsequently diluted approx- imately for assay of its TRF concentration.

TRF in these samples of cerebrospinal fluid was measured by our in vitro pituitary assay method. Twelve separate pools of CSF, each from a minimum of 10 normal animals, yielded a concentration of $18.5 \pm 4.2$ pg TRF/ul CSF.

\section{DISCUSSION}

Experiments directed toward identifying the location of RF-producing cells are important because they may help our understanding of the organization of the endocrine hypothalamus. Early research led to the association of specific hypothalamic regions with the control of specific pituitary tropins, and detailed topographical maps of specific hypothalamic centers were developed. It became clear that such studies, based upon lesion work, electrical stimulation, hormone implantation, etc., did not generally distinguish between the exact locus of the cells producing a particular releasing factor and associated afferent or efferent neural pathways. In the case of the pituitary-thyroid axis, lesions in the anterior hypothalamus, Greer (1951), Ganong et al (1955), Knigge and Bierman (1958), paraventricular nucleus, van Rees and Moll (1968), preoptic area, Knigge \& Joseph (1971) have been shown to alter pituitary-thyroid function. Deafferentation of the basal hypothalamus, Halasz et al (1967), intracerebral thyroxine-implantation, von Euler \& Holmgren (1956), Yamada \& Greer (1959), Yamada (1959a, b), Knigge (1964), Joseph \& Knigge (1972), electrical stimulation of wide areas of the hypothalamus, Campbell et al (1960), D'Angelo \& Snyder (1963), Averill \& Kennedy (1966), Martin \& Reichlin (1972), are capable of both excitation and depression of hypothalamic influence over TSH secretion. In all of these studies the results do not reveal whether the intervention in the CNS was directed at TRF-producing cells or related neural circuits. Mess et al (1970) have summarized the current feeling that TRF is synthesized by cells located widely throughout the hypothala- mus. The discovery of where these cells are located in the hypothalamus remains an important and challenging problem.

Evidence indicates that information concerned with such neuroendocrine phenomena as ovulation, stress, acute cold exposure, etc. may arrive at the hypothalamus by specific pathways. Virtually nothing is known about the subsequent intrahypothalamic distribution of such information. A wide, diffuse distribution of RF-producing cells throughout the hypothalamus would require an equally divergent intrahypothalamic distribution of afferent fibers, assuming that all members of a given pool of RF-producing cells are innervated. In the case of the pituitary-adrenal system, there have been identified discreet afferent pathways which bring certain stressrelated information to the hypothalamus, Greer et al (1970), Gibbs (1969). The intrahypothalamic distribution of this information to CRFproducing cells must be uniquely organized in view of the evidence that these cells are located widely throughout the hypothalamus, Brodish (1963), (1968). Again it must be kept in mind that no evidence exists that the entire pool of CRF-producing cells is functionally homogenous. On the other hand, localization of a specific pool of RF-producing cells to a small, circumscribed locus in the hypothalamus would suggest that the intrahypothalamic pathway of afferents to them could be defined with more anatomical precision. In general, neuroanatomical information currently available on intrahypothalamic distribution of some afferent systems (fornix, stria terminalis, ventral amygdalofugal fibers, ascending nor-adrenergics, etc.) suggest a fairly wide terminal ramification and favors the view of more widespread disposition of these parvicellular neurosecretory cells.

The method of exploring localization of hypothalamic RF-producing cells by the in vitro biosynthesis approach, Mitnick \& Reichlin (1971) clearly circumvents the aforementioned problems inherent in the 
methods used in previous work. The results of our study suggest that some TRF-producing cells may be localized in one discreet region, the arcuate nucleus, and also may be present in a more diffuse dorso-medial zone throughout the entire anteriorposterior extent of the hypothalamus. The results of our assay of endogenous TRF regionally in the mink hypothalamus correlated well with these findings. Endogenous TRF was found to be present in highest amounts in those regions of the hypothalamus which were most active in biosynthesis of the hormone. The localization of stored endogenous TRF and biosynthetic capacity in two separate regions of the hypothalamus correlates with an earlier observation of Averill and Kennedy (1967) that thyrotropinreleasing activity of rat stalk-median eminence extracts was equal to that of extracts of the whole hypothalamus.

The distribution of TRF-producing cells suggested here may provide additional insight into the functional organization of these endocrine motor units of the hypothalamus. The approach of Halasz and Pupp (1965) for isolation ("deafferentation") of the hypothalamus led to the identification of a presumptive "hypophysiotrophic" region within which are located cells responsible for production of all releasing factors. One fundamental assumption made in such studies is that cells located outside the surgically isolated area can no longer be regarded as effective sources of hormone because, according to traditional concept, their axon projections would be denied access to the pituitary portal vessels. In a series of experiments in which progressively smaller amounts of hypothalamus were isolated, Voloschin et al (1968), Joseph et al (1969), Scott \& Knigge (1970), Knigge \& Joseph (1971), Joseph \& Knigge (1972), it was found that basal endocrine function was maintained even after a knife cut which left only the region of the arcuate nucleus in structural continuity with the median eminence. If all RF-producing neurones projected exclusively to the median eminence, these results would suggest that virtually the entire pool of such cells is located in this small region of the arcuate nucleus of the hypothalamus. Considerable indirect evidence could be marshalled to suggest a wider topographical distribution and we suggested Knigge \& Scott (1970), Knigge et al (1971) that RF-producing cells were distributed more widely throughout the hypothalamus and they could possibly deliver their hormones to the median eminence via the cerebrospinal fluid. The delivery of releasing factors via this route would not be impeded by a surgical deafferentation which left hormoneproducing cells ouside the isolated area. The present results confirm a wider distribution of TRF-producing neurones. Our findings, however, also indicate that cells localized in the arcuate nucleus are responsible for approximately $20 \%$ of the TRF synthesized in hypothalamus. These cells of the arcuate nucleus would remain in anatomical contact with the median eminence after surgical isolation of the type performed in our earlier experiments. If $20 \%$ of the pool of TRF-producing cells were sufficient to maintain basal pituitary TSH function, and all the other releasing factors were also represented in the arcuate nucleus, there would be no need to postulate a ventricular route of delivery.

There is evidence however to indicate that this avenue of delivery should be considered. Careful studies of the fine structure of the normal median eminence (Fig. 3) have indicated the presence of a unique structure, the ependyma, which links functionally the CSF of the 3rd ventricle and the pituitaryportal capillaries. Several laboratories Kendall et al (1971), Gordon et al (1972), Knigge et al (1973) have reported that TRF can discharge TSH from the pituitary after intraventricular administration. The presence of a transport mechanism in the median eminence for TRF has been suggested, Knigge \& Silverman (1972), Knigge et al (1973), Knigge (1973). TRF has been localized autoradiographically in

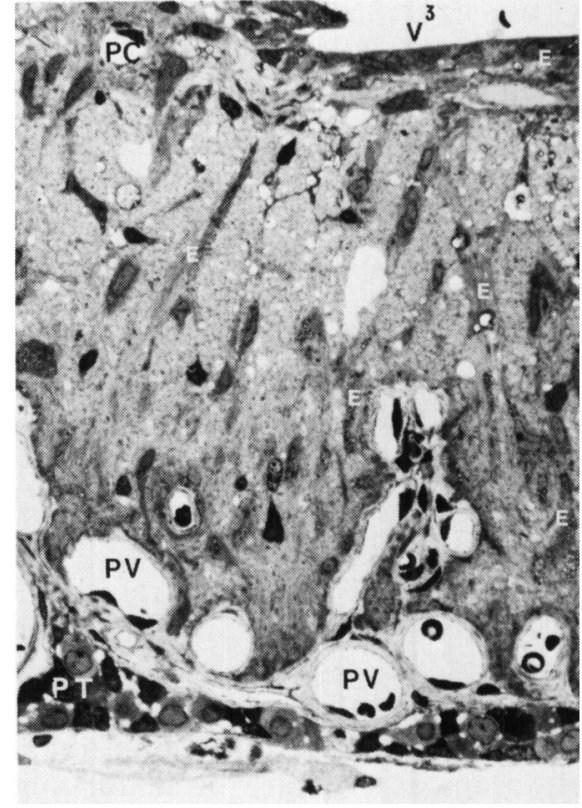

Figure 3-Photomicrograph of inner and outer zones of the median eminence of a normal rat. Most notable in this frontal section are the distinct shafts of ependymal cytoplasm (E) which project from the lumen of the third ventricle $\left(\mathrm{V}^{3}\right)$ to the perivascular space that surround typically fenestrated portal vessels (PV) in the outer zone of the median eminence. Along with tuberoinfundibular axon terminals, ependymal endfeet represent a significantly large surface area which terminate upon the portal bed. Note the portal capillary (PC) which has traversed dorsally into the parenchyma of the inner zone of the median eminence. These portal capillaries, variously referred to as ansae or loops, are common and often invade for some distance into the substance of the median eminence approaching the ventricular lumen. PT, pars tuberalia. X640.

ependyma of the median eminence, Joseph et al (1973), Scott et al (1973). Additional information presented here demonstrates the presence of endogenous TRF in cerebrospinal fluid of the 3 rd ventricle. The amount of hormone observed in the CSF of normal animals $(18 \mathrm{pg} / \mathrm{ul})$ represents a substantial $5 \times 10^{5} \mathrm{M}$ concentration. Conditions which are known to alter hypothalamo-pituitary-thyroid relationships (cold exposure, thyroxine and methimazone treatment) lead to changes in concentration of TRF in third ventricle fluid, Knigge \& Joseph (1973). Using 
chronically implanted cannulae to collect CSF over extended periods of time, we have detected TRF $(0.1-0.2 \mathrm{pg} / \mathrm{ul})$ also in cerebrospinal fluid of the lateral and fourth ventricle of the monkey, Perlow, Knigge, Joseph and Mason (unpublished observations). Experiments of Averill and Kennedy (1967) suggested the presence of TRF in rat cerebrospinal fluid drawn by cisternal puncture. Other hormones have been detected in cerebrospinal fluid including thyroxine, $\mathrm{ADH}$, Heller et al (1968), Vorherr et al (1968), Rodriguez \& Heller (1970), Zimmerman et al (1972), TSH, Bakke (1963), ACTH, Kendall (1973), and CRF, Hiroshige (personal communication).

In addition to the present evidence that some cells of the arcuate nucleus synthesize TRF, we have also observed that certain neurones here take up and bind TRF. In these experiments, ${ }^{3} \mathrm{H}$-TRF, together with sufficient unlabelled hormone to cause release of pituitary TSH,

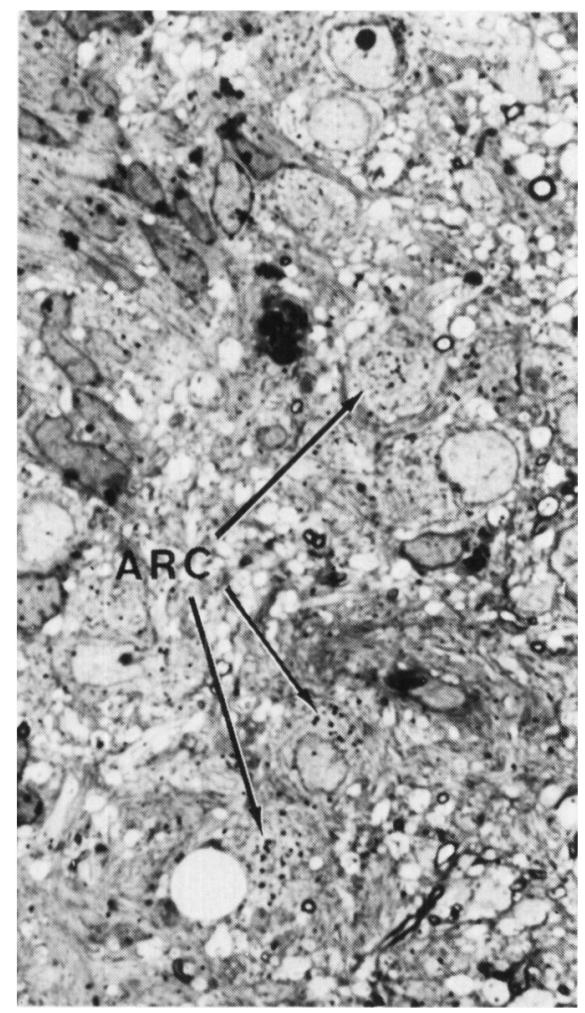

Figure 4-Light microscopic autoradiogram that demonstrates substantial labeling of deep arcuate nucleus (arc) 10 minutes following the intraventricular infusion of $\mathrm{H}^{3}-\mathrm{TRF} . \quad \mathrm{X} 960$.

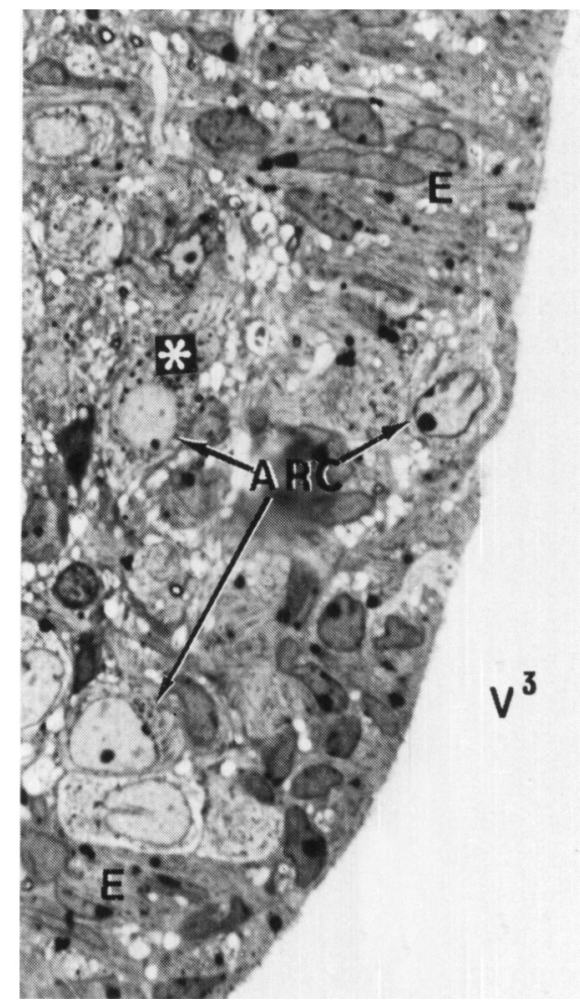

Figure 5-Light microscopic autoradiogram of arcuate neurons (arc) near the ventricular lumen 10 minutes following intraventricular infusion of $\mathrm{H}^{3}$-TRF. In this case only one arcuate neuron (asterisk) appears to be labeled. Silver grains are exclusively sequestered over the cytoplasm. $\mathrm{V}^{3}$; third ventricle. X960.

Knigge et al (1973), was infused into the lateral ventricle. Autoradiographic examination revealed silver grain localization in cells of the arcuate nucleus (Figs. 4,5) and in ependyma of the median eminence (Fig. 6). Uptake by these cells was astonishingly rapid considering the amount of ${ }^{3} \mathrm{H}$-TRF label observed 10 min. after infusion into the lateral ventricle. In vitro incubation of median eminence with ${ }^{3} \mathrm{H}-\mathrm{TRF}$ revealed grain concentration also in ependyma with virtually no evidence of localization in nerve terminals. The cytology of cells of the arcuate nucleus has been examined extensively because some are known to synthesize dopamine and distribute it to the median eminence, Hokfelt \& Fuxe (1972) and others have been suspected of synthesizing RF, Mazzuca (1967), Zambrano \& DeRobertis (1968), Zambrano (1969), Clementi \& Ceccarelli (1970), Brawer (1971). The

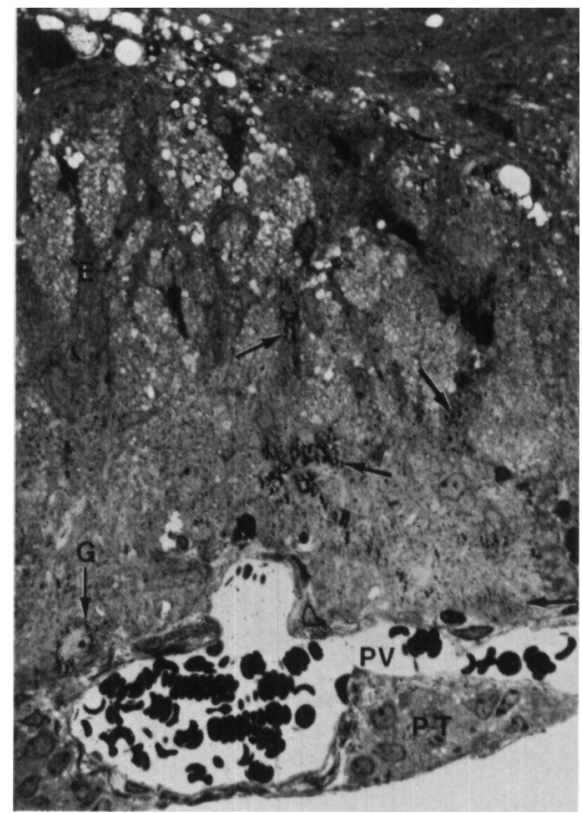

Figure 6-Light microscopic autoradiogram of frontal section of rat median eminence from animal killed 10 minutes following intraventricular infusion of $\mathrm{H}^{3}$-TRF. A heavy deposition of silver grains (arrows) appears over ependymal and glial elements in the outer zone of the median eminence. Since tight junctions (zonulae occludens) obviate the passive interstitial migration of material across lower walls and floor of the third ventricle from the cerebrospinal fluid into surrounding parenchyma, the only mechanisms that can be used to explain the presence of such heavy labeling is that of transependymal transport. G; glial cell with silver grains sequestered over cytoplasm. PV; portal vessel. X640.

apparent nonribosomal enzymatic mechanism of TRF synthesis may explain why we were unable to depress pituitary-thyroid function after implantation of actinomycin into the median eminence-arcuate nucleus region, Knigge (1967). As far as we have been able to determine, the arcuate neurones which bind ${ }^{3} \mathrm{H}$-TRF have no select fine structural attributes which identify them as a separate pool of cells. They contain populations of dense-core vesicles and other intracellular elements similar to those of other cells in the nucleus which did not bind ${ }^{3} \mathrm{H}$-TRF. Without being able to distinguish them from cells which produce dopamine (or other substances) we cannot suggest that these neurones 
are responsible for the synthesis of TRF. It is possible that specific binding of TRF may be occuring in dopaminergic neurones as part of a feedback control mechanism. Binding of other hormones, notably estrogen, Stumpf (1968), Pfaff (1968), occurs in the arcuate nucleus but again without knowledge of the specific secretory product of the neurones in which this hormone is detected autoradiographically.

The presence of TRF-producing neurones in the arcuate nucleus has some implications on the hypothesis of a ventricular route of delivery of this hormone. The axonal projection of these cells, whether to contact zone of the median or adjacent ventricular wall, becomes an issue of considerable interest. The presence of these cells in arcuate nucleus does not immediately imply that their axons project to the median eminence. Dopaminergic neurones of the arcuate nucleus do project to the median eminence, although it is not certain that all of them do so. The lateral portions of the ventricular recess, particularly its roof (underlying the arcuate nucleus) is one of the richest areas in neuronal projection into the ventricular lumen; abundant nerve terminals containing $700-$ $1000 \mathrm{~A}$ dense-core and clear vesicles are found here Scott \& Knigge (1970), Scott et al (1973). Schneider \& McCann (1969), Kamberi et al (1970) and Porter et al (1972) suggest that intraventricularly administered catecholamines exert a significant influence upon delivery of releasing factors to the pituitary. Endogenous dopamine from the arcuate nucleus may perform this role by using secreted into CSF of the ventricular recess. The failure to detect any synthesis of TRF in the median eminence in our study may mean that synthesis does not occur in nerve terminals here or that TRF-producing neurones of the arcuate nucleus do not project to the contact zone. In organ-culture, the median eminence of the guinea pig synthesizes a slight but detectable amount of TRF, whereas hormone formation by a block of tissue including the median eminence and arcuate nucleus is readily observed, McKelvey, Joseph and Sheridan (unpublished observations). The foregoing comments indicate the importance of determining whether TRF synthesized in the arcuate nucleus is delivered axonally to the median eminence or via the cerebrospinal fluid. A most probable answer to this question is that both pathways are used.

With regard to the overall scheme of delivery of TRF to median eminence and pituitary, we suggest that two separate pools of TRF producing cells are present in the hypothalamus and that dual routes of delivery exist. One pool of cells, situated dorso-medially along the antero-posterior extent of the ventricular wall, secrete TRF into the cerebrospinal fluid. A second pool of cells is located in the arcuate nucleus and some or all deliver their product axonally to the contact zone of the median eminence. This organization of the TRF-producing portion of the endocrine hypothalamus would be consistent with much of the information which has been gathered relevant to neural control of TSH secretion. The hypothalamo-pituitary-thyroid axis exhibits perturbations which have acute as well as longer time-courses; the management of such responses would be dealt with appropriately by this proposed dual route of delivery of TRF. In other RF-producing portions of the endocrine hypothalamus (LRF, CRF), control of basal vs. acute discharge of pituitary hormones may be organized in similar fashion.

\section{REFERENCES}

AVERILL, R. L. W., and KENNEDY, T. H. (1966). Increased thyrotrophic hormone secretion after electrical stimulation and hypothalamic extract infusion. New Zealand Medical Journal, 65, 398-402.

AVERILL, R. L. W., and KENNEDY, T. H. (1967) Elevation of thyrotropin release by intrapituitary infusion of crude hypothalamic extracts. Endocrinology, 81, 113-120.

BAKKE, J. L. (1963). The distribution and metabolic fate of thyrotropin. In Thyrotropin, pp. 95-128. Edited by S. C. Werner. C. C. Thomas: Springfield.
BRAWER, J. R. (1971). The role of the arcuate nucleus in the brain-pituitarygonad axis. Journal of Comparative Neurology, 143, 411-446.

BRODISH, A. (1963). Diffuse hypothalamic system for the regulation of ACTH secretion. Endocrinology, 73, 727-735.

BRODISH, A. (1969). Effect of hypothalamic lesions on the time course of corticosterone secretion. Neuroendocrinology, 5, 33-47.

CAMPBELL, H. J., GEORGE, R., and HARRIS, G. W. (1960). The acute effects of injection of thyrotropic hormone or of electrical stimulation of the hypothalamus on thyroid activity. Journal of Physiology, London, 152, 527-544.

CLEMENTI, F., and CECCARELLI, B. (1970). Fine structure of rat hypothalamic nuclei. In The Hypothalamus, pp. 17-44. Edited by L. Martini, M. Motta, and F. Fraschini. Academic Press: New York.

D'ANGELO, S. A., and SNYDER, J. (1963). Electrical stimulation of the hypothalamus and TSH secretion in the rat. Endocrinology, 73, 75-80.

GANONG, W. F., FREDERICKSON, D. S., and HUME, D. M. (1955). The effect of hypothalamic lesions on thyroid function in the dog. Endocrinology, 57, 355-362.

GIBBS, F. P. (1969). Central nervous system lesions that block the release of ACTH caused by traumatic stress. American Journal of Physiology, 217, 78-83.

GORDON, J. H., BOLLINGER, J., and REICHLIN, S. (1972). Plasma thyrotropin responses to thyrotropinreleasing hormone after injection into the third ventricle, systemic circulation, median eminence and anterior pituitary. Endocrinology, 91, 696701.

GREER, M. A. (1951). Evidence of hypothalamic control of pituitary release of thyrotropin. Proceedings, Society for Experimental Biology and Medicine, 77, 603-608.

GREER, M. A., ALLEN, C., GIBBS, F. P., and GULLICKSON, C. (1970). Pathways at the hypothalamic level through which traumatic stress activates ACTH secretion. Endocrinology, 86, 1404-1409.

HALASZ, B., and PUPP, L. (1965). Hormone secretion of the anterior pituitary after partial or total interruption of all nervous pathways to the hypophysiotrophic area. Endocrinology, 77, 553-562. 
HALASZ, B., FLORSHEIM, W. H., CORCORRAN, N. I., and GORSKI, R. S. (1967). Thyrotrophic hormone secretion in rats after partial or total interruption of neural afferents to the median basal hypothalamus. Endocrinology, 80, 1075-1082.

HELLER, H., HASAN, S. H., and SAIFI, A. Q. (1968). Antidiuretic activity in the cerebrospinal fluid. Journal of Endocrinology, 4I, 273-280.

HOKFELT, T., and FUXE, K. (1972): On the morphology and the neuroendocrine role of the hypothalamic catecholamine neurones. In International Symposium on Brain-Endocrine Interaction, Munich, 1971. Median Eminence: Structure and Function, pp. 181-223. Edited by K. M. Knigge, D. E. Scott, and A. Weindle. Karger: Basel.

JOSEPH, S. A., KNIGGE, K. M., and VOLOSCHIN, L. (1969). Effects of isolation of the hypothalamo-pituitary unit in newborn guinea pigs. Neuroendocrinology, 4, 42-50.

JOSEPH, S. A., and KNIGGE, K. M. (1972). Neural regulation of TSH secretion: thyroxine feedback in the newborn. Neuroendocrinology, 10, 197-206.

JOSEPH, S. A., SCOTT, D. E., VAALA, S. S., KNIGGE, K. M., and KROBISCH-DUDLEY, G. (1973). Localization and content of thyrotropin releasing factor (TRF) in median eminence of the hypothalamus. Acta Endocrinologica. (In press.)

KAMBERI, I. A., SCHNEIDER, H. P. G., and McCANN, S. M. (1970). Action of dopamine to induce release of FSH-releasing factor (FRF) from hypothalamic tissue in vitro. Endocrinology, 86, 278-284.

KENDALL, J. W., REES, L. H., and KRAMER, R. (1971). Thyrotropinreleasing hormone (TRH) stimulation of thyroidal radioiodine release in the rat: comparison between intravenous and intraventricular administration. Endocrinology, 88, 1503-1506.

KENDALL, J. W., McGILVRA, R., and LAMORENA, T. L. (1973). (Abstract) ACTH in cerebrospinal fluid and brain. 55th Annual Meeting of the Endocrine Society, Chicago, Illinois, June 1973. Program, p. 79.

KNIGGE, K. M. (1964). Neural regulation of TSH secretion. Effect of diencephalic lesions and intracerebral injection of thyroxine and thyrotropin upon thyroid activity in the cat. In
Major Problems in Neuroendocrinology, pp. 261-285. Edited by E. Bajusz, and G. Jasmin. Karger: Basel.

KNIGGE, K. M. (1967). Brain and endocrine function. American Zoologist, 7, 135-144.

KNIGGE, K. M. (1973). Characteristics of the in vitro binding of ${ }^{3} \mathrm{H}$ thyrotropin releasing factor (TRF) by the organ-cultured median eminence. Anatomical Record, 175, 360.

KNIGGE, K. M., and BIERMAN, S. M. (1958). Evidence of central nervous system influence upon coldinduced acceleration of thyroidal 1-131 release. American Journal of Physiology, 192, 625-630.

KNIGGE, K. M., and SCOTT, D. E. (1970). Structure and function of the median eminence. American Journal of Anatomy, 129, 223-244.

KNIGGE, K. M., and JOSEPH, S. A. (1971). Neural regulation of TSH secretion: sites of thyroxine feedback. Neuroendocrinology, 8, 273285.

KNIGGE, K. M., JOSEPH, S. A., SCOTT, D. E., and JACOBS, J. J. (1971). Observations on the architecture of the arcuate-median eminence region after deafferentation with reference to the organization of hypothalamic RF-producing elements. In Symposium on the Physiology and Pathology of Human Reproduction, 4th, Detroit, 1968. The Neuroendocrinology of Human Reproduction, pp. 6-22. Edited by H. C. Mack, and A. I. Sherman. C. C. Thomas: Springfield.

KNIGGE, K. M., SILVERMAN, A. J., and SCOTT, D. E. (1972). Neurohumoral influences on cellular metabolism in median eminence of the hypothalamus. Proceedings, Federation of American Societies for Experimental Biology. (In press.)

KNIGGE, K. M., and SILVERMAN, A. J. (1972). Transport capacity of the median eminence. In International Symposium on Brain-Endocrine Interaction, Munich, 1971. Median Eminence: Structure and Function, pp. 350-363. Edited by K. M. Knigge, D. E. Scott, and A. Weindle. Karger: Basel.

KNIGGE, K. M., JOSEPH, S. A., SILVERMAN, A. J., and VAALA, S. (1973). Further observations on the structure and function of median eminence, with reference to the organization of RF-producing elements in the endocrine hypothalamus. In Drug
Effects on Neuroendocrine Processes. Edited by B. Marks, and D. DeWied. Elsevier Press: Amsterdam. (In press.)

KNIGGE, K. M., and SILVERMAN, A. J. (1973). The anatomy of the endocrine hypothalamus. In Handbook of Physiology, Section 7: Endocrinology. Edited by R. $\mathrm{O}$. Greep, and E. B. Astwood. Waverley Press: Baltimore. (In press.)

KNIGGE, K. M., and JOSEPH, S. A. (1973). Thyrotropin-releasing factor (TRF) in CSF of third ventricle of rat brain. Acta Endocrinologica. (In press.)

MARTIN, J. B., and REICHLIN, S. (1972). Plasma thyrotropin (TSH) response to hypothalamic electrical stimulation and to injection of synthetic thyrotropin releasing hormone (TRH). Endocrinology, 90, 10791085.

MAZZUCA, M. (1967). Etude preliminaire au microscope electronique du noyau infundibulaire chez le Cobaye. In Neurosecretion, pp. 36-41. Edited by F. Stutinsky. Springer-Verlag: Berlin.

MESS, B., ZANISI, M., and TIMA, L. (1970). Sites of production of releasing and inhibiting factors. In The Hypothalamus, pp. 259-276. Edited by L. Martini, M. Motta, and F. Fraschini. Academic Press: New York.

MITNICK, M., and REICHLIN, S. (1972). Enzymatic synthesis of thyrotropin-releasing hormone (TRH) by hypothalamic TRH synthetase. Endocrinology, 91, 1145-1153.

PFAFF, D. W. (1968). Uptake of estradiol-17B $-\mathrm{H}^{3}$ in the female rat brain. An autoradiographic study. Endocrinology, 82, 1149-1155.

PORTER, J. C., KAMBERI, I. A., and ONDO, J. G. (1972). Role of biogenic amines and cerebrospinal fluid in the neurovascular transmittal of hypophysiotrophic substances. In International Symposium on BrainEndocrine Interaction, Munich, 1971. Median Eminence: Structure and Function, pp. 245-253. Edited by K. M. Knigge, D. E. Scott, and A. Weindl. Karger: Basel.

REDDING, T. W., BOWERS, C. Y., and SCHALLY, A. V. (1966). An in vivo assay for thyrotropin releasing factor. Endocrinology, 79, 229236.

RODRIGUEZ, E. M., and HELLER, H. (1970). Antidiuretic activity and ultrastructure of the toad choroid 
plexus. Journal of Endocrinology, 46, 83-91.

SCHNEIDER, H. P. G., and McCANN, S. M. (1969). Possible role of dopamine as transmitter to promote discharge of LH-releasing factor. Endocrinology, 85, 121-132.

SCOTT, D. E., and KNIGGE, K. M. (1970). Ultrastructural changes in the median eminence of the rat following deafferentation of the basal hypothalamus. Zeitschrift für Zellforschung und Mikroskopische Anatomie, 105, 1-32.

SCOTT, D. E., KOZLOWSKI, G. P., and SHERIDAN, M. N. (1973). Scanning electron microscopy in the ultrastructural analysis of ventricular ependyma. International Review of Cytology. (In press.)

SILVERMAN, A. J., and KNIGGE, K. M. (1972). Transport capacity of median eminence. II: Thyroxine transport. Neuroendocrinology, 10 , 71-82.

SILVERMAN, A. J., KNIGGE, K. M., and PECK, W. A. (1972). Transport capacity of median eminence. I: Amino acid transport. Neuroendocrinology, 9, 123-132.

SILVERMAN, A. J., KNIGGE, K. M., RIBAS, J. L., and SHERIDAN, M. N. (1972). Transport capacity of median eminence. III: Amino acid and thyroxine transport of the organcultured median eminence. Neuroendocrinology. (In press.)

STUMPF, W. F. (1968). Estradiolconcentrating neurones: topograph in the hypothalamus by dry-mount autoradiography. Science, 162,1001 1003.

VAN REES, G. P., and MOLL, J. (1968). Influence of thyroidectomy with and without thyroxine treatment on thyrotropin secretion in gonadectomized rats with anterior hypothalamic lesions. Neuroendocrinology, 3, 115-126.

VOLOSCHIN, L., JOSEPH, S. A., and KNIGGE, K. M. (1968). Endocrine function in male rats following complete and partial isolations of the hypothalamo-pituitary unit. Neuroendocrinology, 3, 387-397.

VON EULER, C., and HOLMGREN, B. (1956). The role of hypothalamohypophysial connexions in thyroid secretion. Journal of Physiology, London, 131, 137-146.

VORHERR, H., BRADBURY, N. W. B., HOGHOUGHI, N., and KLEEMAN, C. R. (1968). Antidiuretic hormone in cerebrospinal fluid during exogenous and endogenous changes in its blood levels. Endocrinology, 83, 246-250.

YAMADA, T. (1959a). Studies on the mechanism of hypothalamic control of thyrotropin secretion. Effect of intrahypothalamic thyroxine injection on thyroid hypertrophy induced by propylthiouracil in the rat. Endocrinology, 65, 216-224.

YAMADA, T. (1959b). Studies on the mechanism of hypothalamic control of thyrotropin secretion. Comparison of the sensitivity of the hypothalamus and of the pituitary to local changes of thyroid hormone concentration. Endocrinology, 65, 920-925.

YAMADA, T., and GREER, M. A. (1959). Studies on the mechanism of hypothalamic control of thyrotropin secretion. Effect of thyroxine injection into the hypothalamus or the pituitary on thyroid hormone release. Endocrinology, 64, 559-566.

ZAMBRANO, D. (1969). The arcuate complex of the female rat during the sexual cycle. An electron microscopic study. Zeitschrift für Zellforschung und Mikroskopische Anatomie, 93, 560-570.

ZAMBRANO, D., and DeROBERTIS, E. (1968). The effect of castration upon the ultrastructure of the rat hypothalamus. II. Arcuate nucleus and outer zone of the median eminence. Zeitschrift Für Zellforschung und Mikroskopische Anatomie, 87, $409-421$. 